\title{
PENGARUH PENGGUNAAN MEDIA PEMBELAJARAN VIRTUAL LAB BERBASIS ANDROID TERHADAP HASIL BELAJAR FISIKA SISWA KELAS VIII SMPN 3 PALU
}

\author{
Weni Anggraeni, Unggul Wahyono dan Darsikin
}

\author{
Jurusan Pendidikan MIPA \\ Fakultas Keguruan dan IImu Pendidikan Universitas Tadulako Palu
}

\begin{abstract}
Abstrak - Penelitian ini bertujuan untuk mengetahui ada tidaknya pengaruh penggunaan media pembelajaran virtual lab berbasis android terhadap hasil belajar fisika siswa kelas VIII SMP N 3 Palu. Jenis penelitian yang digunakan adalah kuasi eksperimen dengan desain the non equivalent pretestposttest design. Sampel penelitian yaitu kelas VIII-J sebagai kelas eksperimen dan kelas VIII-I sebagai kelas kontrol. Instrumen yang digunakan berupa tes hasil belajar dalam bentuk pilihan ganda yang telah divalidasi oleh validator. Dari analisis data, untuk kelas eksperimen diperoleh nilai rata-rata skor posttest adalah 9,57 dengan standar deviasi sebesar 3,35. Sedangkan kelas kontrol diperoleh nilai rata-rata posttest adalah 7,19 dengan standar deviasi sebesar 3,08. Berdasarkan uji hipotesis (uji-t dua pihak) diperoleh thitung $=2,69$ dan $\mathrm{t}_{0,95(60)}=1,67$ pada taraf nyata $\alpha=0,05$. Hal ini berarti $\mathrm{H}_{0}$ ditolak dan $\mathrm{H}_{1}$ diterima. Dengan demikian dapat disimpulkan bahwa ada pengaruh penggunaan media pembelajaran virtual lab berbasis android terhadap hasil belajar fisika siswa kelas VIII SMP N 3 Palu.
\end{abstract}

Kata kunci: media pembelajaran, virtual lab berbasis android, hasil belajar fisika

\section{PENDAHULUAN}

Fisika merupakan pembelajaran eksperimental, yaitu harus dilengkapi dengan percobaan-percobaan oleh guru sebagai demontrasi di depan kelas dan oleh siswa diruang laboratorium atau praktikum. Pembelajaran fisika menekankan pada pengalaman siswa, tujuannya agar siswa dapat bertindak dan menggali informasi sehingga mendapatkan pengalaman yang lebih baik mengenai konsep yang diajarkan. Pembelajaran tersebut sangat cocok jika dilakukan dengan kegiatan praktikum. Konsep pembelajaran fisika disekolah juga banyak yang dilaksanakan melalui kegiatan praktikum.

Seiring kemajuan zaman, siswa menginginkan pembelajaran yang baru untuk dapat belajar dengan menggunakan laptop, tablet, maupun handphone. Untuk itu diperlukanlah aplikasi yang dapat mempermudah dan meningkatkan motivasi siswa, yaitu dengan menggunakan android [1].

Android merupakan sistem operasi dengan sumber terbuka, dan Google merilis kodenya dibawah lisensi Apache. Kode dengan sumber terbuka dan lisensi perizinan pada Android memungkinkan perangkat lunak untuk dimodifikasi secara bebas dan didistribusikan oleh para pembuat perangkat, operator nirkabel, dan pengembang aplikasi [2].

Penggunaan smartphone sebagai media pembelajaran remediasi dipilih karena kepraktisan dan potensi multitasking yang dapat dimanfaatkan untuk aktivitas pendidikan. Berdasarkan hasil survei sebelumnya menemukan $42 \%$ pengguna smarthpone di Indonesia memanfaatkan smartphone mereka untuk aktivitas pendidikan. Jika dibandingkan dengan negara Malaysia 79\% dan Vietnam 53\% pengguna memanfaatkan smartphone mereka untuk aktivitas pendidikan. Hasil tersebut menunjukkan perlu adanya upaya meningkatkan kesadaran pengguna bahwa smartphone yang digunakan sehari-hari dapat difungsikan untuk aktivitas pendidikan. Penggunaan smartphone menjadi cara yang berbeda bagi siswa untuk melakukan kegiatan eksperimen virtual dalam aktivitas pendidikan [3].

Laboratorium riil merupakan laboratorium tempat khusus yang dilengkapi dengan alat-alat dan bahan-bahan riil untuk melakukan percobaan/praktikum baik fisika, kimia atau biologi. Alat laboratorium untuk menguatkan atau memberi kepastian informasi, menentukan hubungan sebab akibat, mempraktekkan sesuatu yang dikehendaki, mengembangkan keterampilan mendorong gairah kepada siswa [4].

Secara umum manfaat yang dapat diperoleh melalui pembelajaran multimedia dalam bentuk laboratorium virtual adalah proses pembelajaran menjadi lebih menarik, lebih interaktif, jumlah waktu mengajar dapat dikurangi, kualitas belajar dapat ditingkatkan dan proses belajar mengajar dapat dilakukan di mana saja dan kapan saja. Selain itu, melalui laboratorium virtual memungkinkan siswa untuk melakukan penghematan eksperimen yang dahulu tidak mungkin untuk dilakukan karena keterbatasan alat dan bahan [5].

Para pendiri LablnApp mengembangkan aplikasi ini dengan tujuan untuk merevolusi proses belajar/mengajar menggunakan 3D realtime computer graphics. Dengan aplikasi LabInApp, kegiatan eksperimen tradisional dapat dilakukan secara virtual menggunakan perangkat yang mendukung pengoperasian aplikasi ini. Untuk mengoperasikan aplikasi LablnApp dapat menggunakan perangkat yang 
berbasis windows, mac, android, google carboard, dan smart board. Dari lima jenis perangkat tersebut dipilih smartphone berbasis android sebagai media pembelajaran hasil belajar siswa [6].

Hasil belajar merupakan kemampuan yang dimiliki siswa setelah ia menerima pengalaman belajarnya. Hasil belajar merupakan hal yang penting yang akan dijadikan sebagai tolak ukur sejauh mana keberhasilan seorang siswa dalam belajar. Dari hasil belajar, guru dapat menilai apakah sistem pembelajaran yang diberikan berhasil atau tidak, untuk selanjutnya bisa diterapkan atau tidak dalam proses pembelajaran [7].

Berdasarkan hasil penelitian [8-10] tersebut dengan penelitian berbeda-beda mengenai media pembelajaran yang masih menggunakan laboratorium virtual berbasis komputer terhadap kemampuan pemecahan masalah dan hasil belajar siswa. Adapun berbasis android tetapi dalam aplikasinya masih bentuk materi. Oleh karena itu, peneliti ingin meningkatkan hasil belajar siswa melalui kegiatan pembelajaran dan mengajak siswa bereksperimen dengan menggunakan virtual lab berbasis android yang melibatkan siswa secara langsung serta berperan aktif.

Tujuan penelitian ini adalah untuk mengetahui ada tidaknya pengaruh penggunaan media pembelajaran virtual lab berbasis android terhadap hasil belajar fisika Siswa kelas VIII SMP N 3 Palu.

\section{METODE PENELITIAN}

Jenis penelitian ini adalah jenis penelitian Eksperimen Kuasi (quasi-experimental). Penelitian kuasi eksperimen ini merupakan penelitian yang berupaya mengungkapkan hubungan sebab akibat dengan cara melibatkan kelompok kontrol dan kelompok eksperimen, dengan pertimbangan sulitnya pengontrolan terhadap semua variabel yang mempengaruhi variabel yang sedang diteliti.

Desain penelitian menggunakan rancangan tes awal-tes akhir yang tidak ekuivalen (the non equivalent, pretest-postest design). Desain penelitian ini digambarkan pada Tabel 1.

TABEL 1 DESAIN PENELITIAN

\begin{tabular}{lccc}
\hline \multicolumn{1}{c}{ Kelas } & Pretest & Perlakuan & Posttest \\
\hline Eksperimen & $\mathrm{O}$ & $\mathrm{X}_{1}$ & $\mathrm{O}$ \\
Kontrol & $\mathrm{O}$ & $\mathrm{X}_{2}$ & $\mathrm{O}$ \\
\hline
\end{tabular}

Keterangan :

$\mathrm{X}_{1}$ : Penggunaan media virtual lab berbasis android

$\mathrm{X}_{2}$ : Penggunaan media laboratorium rill

$\mathrm{O}$ : Tes awal dan tes akhir (pretest dan posttest)

Populasi dalam penelitian ini yaitu seluruh siswa kelas VIII SMP Negeri 3 Palu tahun ajaran 2018/2019. Sampel dari penelitian ini adalah kelas VIII J sebanyak 27 siswa sebagai kelas eksperimen dan VIII I sebanyak 26 siswa sebagai kelas kontrol. Penarikan sampel pada penelitian ini ditentukan dengan menggunakan teknik purposive sampling atau penentuan sampel dengan pertimbangan tertentu.

Instrumen yang digunakan dalam penelitian ini antara lain: (1) Perangkat pembelajaran meliputi silabus, rencana pelaksanaan pembelajaran (RPP), lembar kerja siswa (LKS), dan media pembelajaran; (2) Tes hasil belajar dimana pada penelitian ini materi yang diajarkan dengan menyesuaikan materi yang masih berlaku di sekolah. Tes ini digunakan untuk mengetahui hasil belajar fisika pada kelas yang menjadi sampel penelitian. Tes dibuat dalam bentuk pilihan ganda (PG) sebanyak 16 soal dan untuk memperoleh tes yang standar, dilakukan validasi ahli.

Data yang diperoleh dari penelitian ini selanjutnya diolah dengan menggunakan uji statistik berupa uji normalitas, uji homogenitas, dan uji hipotesis (uji-t dua pihak).

\section{HASIL DAN PEMBAHASAN}

\section{Hasil Penelitian}

Pengolahan data pretest dan posttest untuk masing-masing kelas yaitu kelas eksperimen dan kelas kontrol, diperoleh nilai maksimum, nilai minimum, nilai rata-rata dan standar deviasi. Seperti pada Tabel 2 berikut. 
TABEL 2 DESKRIPSI SKOR TES HASIL BELAJAR PRETEST DAN POSTTEST

\begin{tabular}{lcccc}
\hline \multirow{2}{*}{ Deskripsi } & \multicolumn{2}{c}{$\begin{array}{c}\text { Kelas VIII J } \\
\text { (Eksperimen) }\end{array}$} & Kelas VIII I \\
& Pretest & Posttest & Pretest & Posttest \\
\cline { 2 - 5 } & 27 & 27 & 26 & 26 \\
\hline Sampel & 2 & 5 & 1 & 3 \\
\hline Skor minimum & 13 & 15 & 4,88 & 7,19 \\
\hline Skor maksimum & 6,13 & 9,57 & 2,93 & 3,08 \\
\hline Skor rata-rata & 3,14 & 3,35 & & \\
\hline Standar deviasi & & & & 12 \\
\hline
\end{tabular}

Uji normalitas pada penelitian ini menggunakan uji Chi-kuadrat. Hasil uji Chikuadrat dengan kriteria penerimaan $\mathrm{x}^{2}$ hitung $<\mathrm{X}^{2}$ tabel, taraf signifikasi $\alpha=0,05$ danderajat kebebasan $\mathrm{dk}=\mathrm{k}-3$. Hasil uji normalitas posttest dapat dilihat pada Tabel 3.

TABEL 3 NORMALITAS DISTRIBUSI POSTTEST

\begin{tabular}{|c|c|c|}
\hline \multirow{2}{*}{ Uraian } & \multicolumn{2}{|c|}{ Posttest } \\
\hline & Eksperimen & Kontrol \\
\hline Sampel & 27 & 26 \\
\hline Skor rata-rata & 9,57 & 7,19 \\
\hline Simpangan baku (s) & 3,35 & 3,08 \\
\hline$X^{2}$ hitung & 5,43 & 3,99 \\
\hline $\mathrm{X}^{2}$ tabel & \multicolumn{2}{|c|}{7,81} \\
\hline Keterangan & \multicolumn{2}{|c|}{ Normal } \\
\hline
\end{tabular}

Dari tabel terlihat bahwa nilai $\mathrm{x}^{2}$ hitung kelas eksperimen maupun kelas kontrol lebih kecil daripada nilai $X^{2}(1-\alpha)(k-3)$. Artinya, hasil ini menunjukan bahwa data Posttest kelas eksperimen maupun kelas kontrol terdistribusi normal.
Pengujian data homogenitas ini menggunakan uji-F dengan kriteria jika $F_{\text {hitung }}<$ $F_{\text {tabel }}$ maka data homogen. Hasil uji homogenitas dari kelas eksperimen dan kelas kontrol dapat dilihat pada Tabel 4.

TABEL 4 UJI HOMOGENITAS POSTTEST

\begin{tabular}{lll}
\hline Uraian & Posttest & Keterangan \\
\hline$F_{\text {hitung }}$ & 1,18 & Homogen \\
\hline$F_{\text {tabel }}$ & 1,90 & \\
\hline
\end{tabular}

Hasil uji homogenitas posttest dengan taraf signifikasi $\alpha=0,05$ dan nilai $F_{\text {hitung }}<F_{\text {tabel. Nilai }}$ $F_{\text {hitung }}=1,18<F_{\text {tabel }}=1,90$. Dengan demikian data posttest tersebut menunjukkan kedua kelas yang dijadikan sampel berasal dari populasi yang homogen.

Setelah terpenuhinya uji normalitas dan homogenitas, maka dilakukam uji-t dua pihak. Uji-t tersebut diperoleh berdasarkan data posttest.

TABEL 5 UJI BEDA RERATA (DUA PIHAK) EKSPERIMEN DAN KONTROL

\begin{tabular}{|c|c|c|c|c|}
\hline Kelas & - & thitung & tabel & Keputusan \\
\hline Eksperimen & 9,57 & \multirow{2}{*}{2,69} & \multirow{2}{*}{1,67} & \multirow{2}{*}{$\mathrm{H}_{1}$ diterima } \\
\hline Kontrol & 7,19 & & & \\
\hline
\end{tabular}

Hasil uji beda 2 rerata (dua pihak) pada Tabel 5 diketahui $-1,67<2,69>1,67$. Hal ini menunjukkan bahwa nilai thitung berada diluar daerah penerimaan $\mathrm{H}_{\mathrm{o}}$. Dengan demikian $\mathrm{H}_{0}$ ditolak sedangkan $\mathrm{H}_{1}$ diterima. Hal ini dapat disimpulkan bahwa terdapat pengaruh penggunaan media pembelajaran virtual lab berbasis android terhadapa hasil belajar fisika siswa kelas VIII SMPN 3 Palu.

\section{Pembahasan}

Dari perolehan hasil data tes awal (pretest) kelas eksperimen dan kontrol memiliki skor ratarata sebesar 6,13 dengan standar deviasi 
sebesar 3,14 dari 27 siswa dan 4,88 dengan standar deviasi sebesar 2,93 dari 26 siswa. Dari hasil tersebut menunjukkan bahwa terdapat selisih yang relatif kecil antara kelas eksperimen dan kontrol. Hal ini karena kedua kelas samasama berdistribusi merata dan kedua kelas belum mendapatkan pembelajaran tentang materi getaran.

Berdasarkan hasil analisis data, tes akhir (posttest) diperoleh nilai rata-rata siswa pada untuk kelas eksperimen sebesar 9,57 dengan standar deviasi sebesar 3,35 dari 27 siswa dan kelas kontrol sebesar 7,19 dengan standar deviasi sebesar 3,08 dari 26 siswa. Dimana kelas eksperimen menerima materi getaran dengan menggunakan media pembelajaran virtual lab berbasis android sedangkan kelas kontrol menerima materi getaran dengan menggunakan media pembelajaran laboratorium riil. Hasil tersebut menunjukkan bahwa data (posttest) berdistribusi normal dan memilki varians yang homogen. Kemudian dilakukan uji hipotesis (menggunakan uji dua pihak) dan didapatkan bahwa hasil belajar kelas eksperimen lebih besar dibanding kelas kontrol.

Berdasarkan uji hipotesis (uji t) pada pretest dan posttest yang dilakukan bahwa uji dua pihak tes awal menunjukkan $\mathrm{H}_{0}$ diterima dan $\mathrm{H}_{1}$ ditolak sedangkan pada tes akhir $\mathrm{H}_{0}$ ditolak dan $\mathrm{H}_{1}$ diterima. Kesimpulan dari hipotesis tersebut adalah hasil belajar siswa yang menggunakan media pembelajaran virtual lab berbasis android lebih tinggi dibandingkan hasil belajar siswa yang menggunakan media pembelajaran laboratorium riil. Karena kelas eksperimen melakukan praktikum dengan baik dan teliti sehingga kesalahan peralaks tidak ada, tetapi terdapat kesalahan manusia disebabkan adanya kurang konsentrasi, dan salah menekan saat melakukan percobaan sedangkan kelas kontrol melakukan dengan baik tetapi tidak teliti sehingga kesalahan paralaks dan kesalahan manusia lebih besar, kesalahan inilah membuat hasil belajar siswa menurun. Hal ini dapat terjadi kesalahan ketika kedua kelas melakukan percobaan.

Ketika praktik berlangsung, siswa kelas eksperimen lebih cenderung mengamati perlakuan yang diberikan oleh guru, saat siswa diberikan perlakuan mereka langsung berdiskusi dengan teman sekelompoknya untuk melihat dan melakukan pengamatan berdasarkan pengetahuan awal mereka. Dimana dari perlakuan tersebut mereka mengetahui 1 kali getaran karena dalam virtual lab tersebut sudah tertulis jumlah getaran dan waktu ketika mencapai jumlah getaran tersebut. Hal ini menunjukkan bahwa siswa lebih bersemangat dan lebih aktif dalam praktikum karena dapat membantu untuk memecahkan masalah dengan lebih praktis sehingga kesalahan paralaks tidak ada. Kemudian pada saat melakukan percobaan dalam menarik tali simpangan siswa kadang melewati ukuran yang telah ditentukan sehingga terjadi kesalahan manusia karena kurangnya konsentrasi dan salah menekan pada pengukuran simpangan. Ini menunjukkan bahwa meskipun kelas ekperimen tidak ada kesalahan paralaks, tetapi terdapat kesalahan manusia. Selain itu, dengan adanya jawaban yang tepat dari hasil praktikum akan mengklarifikasi hipotesis siswa sebelumnya yang masih keliru. Hal inilah yang membuat siswa lebih memahami dengan benar materi pelajaran yang diajarkan.

Berbeda pada kelas kontrol dengan menggunakan media pembelajaran laboratorium riil ini masih terdapat siswa yang kurang aktif dalam proses praktikum, terutama pada saat berdiskusi dengan teman satu kelompok menyebabkan kondisi kelas menjadi lebih ramai, dan hanya tiga atau empat orang saja dalam satu kelompok tersebut yang aktif dalam kegiatan praktikum baik dari pengamatan, pengambilan data, serta membuat kesimpulan. Sedangkan teman kelompok yang lain lebih cenderung pasif dan tidak terlibat langsung dalam proses praktikum atau terkadang teman yang tidak mengikuti praktikum lebih memilih untuk mengganggu kelompok lain dan tidak membantu teman satu kelompoknya. Selama praktikum berlangsung, siswa menggunakan stopwatch untuk mengetahui waktu ketika mencapai jumlah getaran, dimana siswa harus menghitung jumlah getaran dan menyebut angka dengan nada suara keras ataupun sedang. Hal ini dapat mempengaruhi kesalahan dalam praktikum misalnya pada stopwatch ketika jumlah getaran hampir tercapai siswa lambat atau cepat menekan stopwatch tersebut begitupula menghitung jumlah getaran. Hal ini menyebabkan kesalahan paralaks dan kesalahan manusia lebih banyak yang disebabkan kurangnya konsentrasi siswa karena terganggu dengan suara kelompok lainnya. Beberapa kelemahan itulah yang menghambat proses penemuan konsep, prinsip atau fakta yang sedang dipelajari sehingga membuat hasil belajar yang lebih rendah dibandingkan dengan kelas virtual lab.

Selain kesalahan-kesalahan yang terjadi diatas, adapun ketertarikan siswa pada penggunaan media pembelajaran virtual lab berbasis android, memberikan gairah baru siswa dan rasa senang bahkan tidak percaya bahwa ada aplikasi android LabInApp yang dapat membantu mereka untuk melakukan percobaan tanpa harus ke laboratorium lagi. Hal ini dapat menimbulkan ketertarikan siswa dalam pelaksanaan praktikum maupun pembelajaran. Sehingga dari ketertarikan tersebut menjadikan siswa termotivasi belajar dan membuat siswa lebih aktif dalam pembelajaran serta 
menumbuhkan kemauan belajar siswa yang berdampak pada meningkatnya hasil belajar.

Hal ini dapat dilihat bahwa dengan memberikan perlakuan yang berbeda pada kelas ekperimen dan kelas kontrol, akan memperoleh hasil belajar fisika yang berbeda. Perbedaan hasil belajar tersebut dapat dilihat dari skor pretest maupun skor posttest pada kelas ekperimen dan kelas kontrol yang menunjukkan adanya pengaruh media pembelajaran yang digunakan pada kedua kelas tersebut. Pengaruh hasil belajar yang lebih baik terjadi pada kelas eksperimen, karena kelas ekperimen menggunakan media pembelajaran virtual lab. Siswa pada kelas eksperimen aktif dalam proses praktikum serta memudahkan siswa dalam memecahkan masalah tanpa dituntut pengetahuan awal. Sedangkan pada kelas kontrol siswa dituntut untuk mempunyai modal pengetahuan awal tentang praktikum seperti mengetahui nama-nama bahan dan alatalat yang akan digunakan dan lebih teliti sehingga siswa harus memiliki keaktifan serta skill atau kemampuan yang tinggi baik sendiri maupun bersama kelompoknya.

Pernyataan tersebut sesuai dengan penelitian yang dilakukan oleh Suhendar [7] yang menyatakan bahwa hasil dari analisis angket dapat menunjukkan kecenderungan ketertarikan siswa terhadap media pembelajaran. Hal ini karena kemudahan akses dan penyampaian materi yang mudah dipahami oleh siswa. Penggunaan bahasa dan tampilan isi juga memiliki presentase yang cukup tinggi. Data yang didapat secara keseluruhan didapatkan presentase angket yang termasuk dalam kategori baik. Sehingga dapat disimpulkan bahwa penggunaan media pembelajaran berbasis aplikasi android mendapat respon positif dari siswa. Hal ini sejalan dengan penelitian Darti, dkk [8] yang menyatakan bahwa media laboratorium virtual dapat membawa siswa kedalam suasana belajar yang bermakna karena siswa dapat secara aktif bekerja sama dengan sesama siswa dalam suasana gotong royong dalam upaya menggali informasi dan meningkatkan kemampuan berkomunikasi untuk meningkatkan kemampun pemecahan masalah siswa pada materi pelajaran yang sedang dipelajari. Dan didukung oleh penelitian Quddus, dkk [9] yang menyatakan bahwa dengan adanya laboratorium virtual ini, sangat membantu siswa dalam meningkatkan pengalaman belajar yang lebih efektif. Selain itu respon siswa terhadap penggunaan simulasi juga sangat positif. Respon positif ini menunjukan bahwa siswa antusias dengan pembelajaran yang disajikan. Hal ini dapat memotivasi siswa untuk meningkatkan perhatian dan membuat mereka terlibat dalam pengalaman pembelajaran yang menyenangkan dan bermakna.
Kelebihan virtual lab yaitu mudah dioperasikan tanpa harus ke laboratorium lagi, dapat digunakan dalam keadaan offline dan dapat mengurangi waktu praktikum jadi tidak perluh membutuhkan banyak waktu seperti melakukan praktikum secara langsung. Sedangkan kelemahannya yaitu siswa harus mempunyai handphone android, terbatasnya pengetahuan siswa mengenai tata cara pelaksanaan praktikum, karena kebanyakan penyedia layanan virtual lab menggunakan bahasa inggris dan virtual lab tidak memberikan pengalaman di lapangan secara nyata. Hal ini sesuai dengan penelitian yang terjadi di sekolah dan selaras dengan penelitian yang telah dilakukan oleh peneliti sebelumnya.

\section{KESIMPULAN DAN SARAN}

\section{Kesimpulan}

Berdasarkan hasil penelitian, setelah menggunakan media pembelajaran virtual lab berbasis android, menunjukkan adanya pengaruh hasil belajar fisika siswa kelas VIII SMP Negeri 3 palu yang menggunakan media pembelajaran tersebut. Dapat dilihat dari hasil uji hipotesis memperoleh nilai untuk thitung $=$ $2,69>$ tabel $_{\text {tab }}=1,67$, taraf signifikasi $\alpha=0,05$ maka $\mathrm{H}_{0}=$ ditolak atau $\mathrm{H}_{1}$ diterima. Hal ini menunjukkan bahwa hipotesis menyatakan $\mathrm{H}_{0}$ ditolak sedangkan $\mathrm{H}_{1}$ diterima. Maka dapat disimpulkan bahwa siswa yang menggunakan media pembelajaran virtual lab berbasis android terdapat pengaruh hasil belajar fisika siswa kelas VIII SMP Negeri 3 Palu

\section{Saran}

Dari hasil penelitian yang telah dilakukan, kepada guru bahwa dapat dijadikan sebagai salah satu alternatif media pembelajaran, jika di sekolah tersebut keterbatasan atau belum mempunyai peralatan laboratorium. Dan untuk peneliti selanjutnya dapat menerapkan penggunaan media pembelajaran virtual lab berbasis android dengan membandingkan media pembelajaran lainnya.

\section{DAFTAR PUSTAKA}

[1] I. Samarudin, "Jurnal Informatika," Perancangan Aplikasi Pembelajaran Fisika Kelas XII SMA Berbasis Android, vol.2, no.10;100-137, 2014.

[2] M. Hilmi, Buku Pintar Android, Jakarta: Media Kumputindo, 2015.

[3] J. Poushter, "Pew Research Center," Smartphone Ownership and Internet Usage Continues to Climb in Emerging Economies, vol.6, no.10;1-44, 2016.

[4] Mujiono, "Jurnal Pendidikan," Penerapan Laboratorium Riil dan Virtual pada Pembelajaran Biologi Ditinjau dari Gaya 
Pengaruh Penggunaan Media Pembelajaran Virtual Lab Berbasis Android Terhadap Hasil Belajar Fisika Siswa Kelas VIII SMPN 3 Palu (Weni Anggraeni)

Belajar dan Kemampuan Memori Siswa, vol.4, no.2;198-204, 2015.

[5] R. Nirwana, "Jurnal Phenomenon," Pemanfaatan Laboratorium Virtual Dan EReference Dalam Proses Pembelajaran Dan Penelitian IImu Kimia, vol.1, no.1; 115123, 2011.

[6] A. Lintang, "Jurnal Pendidikan," Remediasi Miskonsepsi Menggunakan Metode Interactive Problem Task And Experiment Berbantuan Labinapp Tentang Getaran Di SMP, vol.1, no.1;211-226, 2017.

[7] S. Wahyuni, "Jurnal Pendidikan," Pengaruh Jenis Laboratorium terhadap Respon Siswa, vol.11, no.1;74-86, 2010.
[8] Suhendar, Wijayati, dan Mahatmanti, "Jurnal Inovasi Pendidikan Kimia," Pengaruh Penggunaan Media Pembelajaran Berbasis Aplikasi Android Terhadap Hasil Belajar Siswa, vol.11, no.2;2009-2018, 2017.

[9] Darti, Fuadunazmi, dan Budi, "Jurnal IImiah Pendidikan Fisika lensa," Pengaruh Penggunaan Media Laboratorium Virtual Fisika Terhadap Kemampuan Pemecahan Masalah Siswa, vol.3, no.2;300-303, 2017.

Quddus, Hamid, dan Kasli, "Jurnal Ilmiah Mahasiswa (JIM) Pendidikan Fisika," Perbandingan Hasil Belajar Fisika Dengan Menggunakan Laboratorium Nyata dan Laboratorium Virtual, vol.2, no.1;122-127, 2017. 